\title{
Editorial: How Reproductive History Influences Our Breast Cancer Risk
}

\author{
Robin L. Anderson ${ }^{1,2}$, Wendy V. Ingman ${ }^{3,4}$ and Kara L. Britt ${ }^{5,6 *}$ \\ ${ }^{1}$ Metastasis Research Laboratory, Olivia Newton-John Cancer Research Institute, Heidelberg, VIC, Australia, ${ }^{2}$ School of \\ Cancer Medicine, LaTrobe University, Bundoora, VIC, Australia, ${ }^{3}$ School of Medicine at The Queen Elizabeth Hospital, \\ University of Adelaide, Adelaide, SA, Australia, ${ }^{4}$ Robinson Research Institute, University of Adelaide, Adelaide, SA, Australia, \\ ${ }^{5}$ Breast Cancer Risk and Prevention, Peter MacCallum Cancer Centre, Melbourne, VIC, Australia, ${ }^{6}$ The Sir Peter MacCallum \\ Department of Oncology, University of Melbourne, Parkville, VIC, Australia
}

Keywords: estrogen, breast cancer risk, pregnancy, parity, lymphangiogenesis, obesity

\section{Editorial on the Research Topic}

\section{How Reproductive History Influences Our Breast Cancer Risk}

Reproductive history has profound effects on women's breast cancer (BCa) risk. With fertility rates falling, the age of childbearing increasing, and the age of menarche decreasing each decade, it is critically important that we define the biological pathways linking reproductive history to BCa risk. In this special series on reproductive history and breast cancer risk, we hear from six groups who have expertise in this area and share their thoughts on the most pressing questions in the field.

Dall and Britt have an interest in the effects of hormones and reproductive events (menarche, parity, menopause) on breast cancer risk. They describe the increased risk of breast cancer in nulliparous

\section{OPEN ACCESS}

Edited by:

Sarah M. Temkin,

National Cancer Institute (NIH),

United States

Reviewed by:

Lisa Rubinsak,

Virginia Commonwealth University,

United States

${ }^{*}$ Correspondence:

Kara L. Britt

kara.britt@petermac.org

Specialty section:

This article was submitted to Women's Cancer,

a section of the journal

Frontiers in Oncology

Received: 08 September 2017 Accepted: 13 November 2017

Published: 04 December 2017

Citation:

Anderson RL, Ingman WW and

Britt KL (2017) Editorial: How

Reproductive History Influences Our

Breast Cancer Risk.

Front. Oncol. 7:289.

doi: 10.3389/fonc.2017.00289 nuns and discuss the current studies attempting to define the role of the mammary stem cells, ER+ cells, and growth factors in parity-induced protection $(1,2)$. In contrast to the decreased risk that comes with pregnancy, a woman's risk of ER+ BCa increases is she is older when she enters menopause $(3,4)$. Polymorphisms in the ER gene, ER signaling $(5,6)$, DNA damage/repair, and FSH and immune components $(7-10)$ have been associated with the age at menopause but together still only explain a small portion of the timing. As mice do not undergo a natural menopause, experimental data on menopause and breast cancer are lacking. The other reproductive time point to influence cancer risk is the age at menarche; a younger age at menarche increasing BCa risk. This is worrying as the age of menarche has declined from 16.5 years in the $1800 \mathrm{~s}, 13.5$ in the early $1900 \mathrm{~s}$, to 12 years today. Biologically, menarche begins in response to rising circulating hormones including estrogen, and elevated estrogens have been found in girls experiencing precocious menarche (11). Despite this, genome-wide sequencing studies failed to find a strong association with estrogen-regulated genes $(9,12,13)$. Hormone replacement therapy and oral contraceptive pill use both increased BCa risk in current users and can have more detrimental effects on younger users $(14,15)$. Together, this work highlights that the young breast is particularly sensitive to hormonal changes.

Atashgaran and colleagues study the influence of the reproductive cycle on immune cells within the breast and how this might relate to the increased risk of $\mathrm{BCa}$ in women who cycle for extended periods. They explain the effects of fluctuating estrogen and progesterone (during menstrual cycling) on the mammary epithelial cells, immune cells, and extracellular matrix. The ability of transformed cells to evade the immune response is a hallmark of cancer (16). Fluctuations in hormones during the mouse estrous cycle alters the abundance, phenotype, and function of local macrophages $(17,18)$, which can affect their ability to recognize DNA-damaged cells, phagocytose them, and generate adaptive immune responses (18). In particular, progesterone regulates the Th1/Th2 phenotypes of T cells in the mammary gland (19) and induces Th2 cytokines during pregnancy (20). Th1 cytokines are thought to mediate antitumor immunity and tumor rejection, whereas Th2 cytokines are produced by tumors and are involved in pro-tumorigenic responses $(21,22)$. Estradiol induces a pro-inflammatory cytokine profile in the estrus phase that can be mitigated by progesterone during 
other phases of the cycle (23). It is possible that aberrant hormonal exposure can negatively influence the inflammatory milieu of the breast and aid in tumor development and cancer progression.

Katz and her team have been trying to understand the role of insulin-like growth factors (IGF) in parity-induced protection against breast cancer. They dissected mammary glands from parous mice and age-matched virgins and a found Igf1r to be hypermethylated and silenced in parous mammary glands (2) aligning with the fact that high IGF1 levels are associated with increased BCa risk $(24,25)$. Parous mice, with a low tumor incidence (16\%) compared to nulliparous mice (100\%) treated with carcinogen, had their protective effect eliminated if they were first treated with IGF (83\%) (26). This work is supported by a recent DNA methylation study performed on parous and nulliparous women showing that the IGF acid labile subunit (responsible for transport of IGF1 in the circulation) was hypomethylated with parity (27). Unfortunately, targeting the IGF pathway using IGF1R inhibitors leads to toxic effects that will limit their use as a preventative (28-30); however, this work highlights the importance of exploring other options to promote the parity-associated breast cancer protection.

While there is a lot of interest in trying to define the role of hormones in parity-induced protection, prior to the protection instilled by parity, each woman passes through a transient increased risk period. Borges and colleagues have been studying this postpartum period of mammary gland involution, characterized by regression and remodeling of the epithelium. Postpartum $\mathrm{BCa}$ is diagnosed within 5 years of a woman's most recent childbirth $(31,32)$, and these cancers tend to be of poor prognosis with an increased likelihood to metastasize (31-34). Similarly, tumor cells implanted into postpartum murine hosts have increased growth, invasive and metastatic capacities compared to those implanted in nulliparous controls (35-39). This environment is driven by immunosuppression and lymphangiogenesis and, here, Borges and colleagues review the role for lymphangiogenesis, the outgrowth of new lymphatic vessels (40-42). New lymphatic formation or neo-lymphangiogenesis occurs in adult tissues in response to infection, inflammation, and wound healing and is stimulated by vascular endothelial growth factors within the damaged tissue. The growth factors VEGF-A, - C, and -D produced by the local fibroblasts, inflammatory cells, and macrophages bind to their receptors on nearby lymphatic endothelial cells and cause the lymphatics to expand (43-47). Borges et al. have shown that neo-lymphangiogenesis occurs during postpartum mammary gland along as does an upregulation of VEGF-C, VEGF-D, and their receptors (36). This increase in lymphatic vessel density in the postpartum breast (1-5 years post pregnancy) may explain the increased likelihood of tumor development in these women who make up a large proportion of all $\mathrm{BCa}$ diagnosed in young ( $<45$ years) Caucasian women $(33)$.

$\mathrm{Au}$ and colleagues work on the role of adipose-derived estrogen in breast cancer development. Local estrogen production (through the enzyme aromatase) is increased in tumor-bearing breast tissue and systemic antiestrogen therapies are widely used to target this in ER+ BCa patients. These hormonally driven $\mathrm{BCa}$ are more prevalent in postmenopausal women where an increased BMI has been associated with increased local breast estrogen (48-50). In these women, the adipose tissue (rather than the ovaries) is the primary site of estrogen production (51). Aromatase is increased in breast adipose tissue of obese women as a number of obesity-associated factors (inflammatory mediator PGE2 and the adipokine leptin) can stimulate aromatase expression $(52,53)$. Au and colleagues have tried to find a factor that inhibits aromatase expression in the adipose as a novel targeted antiestrogen therapy. They found that the gut-derived hormone ghrelin (produced in the stomach to regulate appetite and growth hormone release) inhibits aromatase expression in adipose cells $(54,55)$. In addition, circulating levels of ghrelin, and its unacetylated form des-acyl ghrelin, are lower in obese women and cannot function as well to inhibit estrogen-driven BCa growth. They describe the work they are now doing on Ghrelin/des-acyl ghrelin mimetics as alternative endocrine therapeutics.

In order to define how aggressive a tumor is and possibly identify if it would be responsive to endocrine therapy, clinics are adopting gene-expression profiling on the tumors to provide an intrinsic, molecular portrait of the tumor and identify the likelihood of recurrence. Bernhardt and colleagues are concerned that these tests have been developed using tumor tissue from postmenopausal women (non-cycling) but are being used for women at all ages. Of the gene expression tests available (PAM50, Oncotype DX and EndoPredict) were developed in postmenopausal women and now not performing well in premenopausal women who make up $25 \%$ of all patients $(56-58)$. It is postulated that this is because the tests are largely reliant on proliferation and estrogen signaling genes, which are expected to differ markedly in pre- and postmenopausal women. The former undergo cyclical production of ovarian hormones which drive proliferation, differentiation, and apoptosis through gene expression changes $(59,60)$. These hormonally driven changes are not present in the postmenopausal women. Supporting these concerns, it has been found that the MammaPrint gene expression test that was developed and validated in women under 55 years of age $(61,62)$ is performing well for younger women. This suggests that for the most success in guiding clinical treatment, gene-expression tests should be developed in the women for which we intend to use them.

\section{AUTHOR CONTRIBUTIONS}

RA: this author assisted in the design and was involved in reviewing articles. Assisted with drafting the editorial and approved final version. WI: this author wrote two review articles and was involved in reviewing articles. She assisted with drafting the editorial and approved final version. KB: this author was the lead editor and conceived the special issue. Invited all contributors, wrote a review article, and assisted with reviewing articles. Wrote the editorial.

\section{ACKNOWLEDGMENTS}

RA was supported by an NBCF grant PS-15-022 fellowship. WI was supported by an NBCF and THRF fellowship. KB was supported by an NBCF grant PS-16-021 fellowship and an NHMRC new investigator grant. 


\section{REFERENCES}

1. Dall G, Risbridger G, Britt K. Mammary stem cells and parity-induced breast cancer protection - new insights. J Steroid Biochem Mol Biol (2017) 170:54-60. doi:10.1016/j.jsbmb.2016.02.018

2. Katz TA, Liao SG, Palmieri VJ, Dearth RK, Pathiraja TN, Huo Z, et al. Targeted DNA methylation screen in the mouse mammary genome reveals a parityinduced hypermethylation of Igf1r that persists long after parturition. Cancer Prev Res (Phila) (2015) 8(10):1000-9. doi:10.1158/1940-6207.CAPR-15-0178

3. Collaborative Group on Hormonal Factors in Breast Cancer. Menarche, menopause, and breast cancer risk: individual participant meta-analysis, including 118964 women with breast cancer from 117 epidemiological studies. Lancet Oncol (2012) 13(11):1141-51. doi:10.1016/S1470-2045(12)70425-4

4. Sisti JS, Collins LC, Beck AH, Tamimi RM, Rosner BA, Eliassen AH. Reproductive risk factors in relation to molecular subtypes of breast cancer: results from the nurses' health studies. Int J Cancer (2016) 138(10):2346-56. doi:10.1002/ijc.29968

5. He LN, Xiong DH, Liu YJ, Zhang F, Recker RR, Deng HW. Association study of the oestrogen signalling pathway genes in relation to age at natural menopause. J Genet (2007) 86(3):269-76. doi:10.1007/s12041-007-0034-7

6. Weel AE, Uitterlinden AG, Westendorp IC, Burger H, Schuit SC, Hofman A, et al. Estrogen receptor polymorphism predicts the onset of natural and surgical menopause. J Clin Endocrinol Metab (1999) 84(9):3146-50. doi:10.1210/ jc.84.9.3146

7. He C, Kraft P, Chasman DI, Buring JE, Chen C, Hankinson SE, et al. A large-scale candidate gene association study of age at menarche and age at natural menopause. Hum Genet (2010) 128(5):515-27. doi:10.1007/ s00439-010-0878-4

8. Perry JR, Hsu YH, Chasman DI, Johnson AD, Elks C, Albrecht E, et al. DNA mismatch repair gene MSH6 implicated in determining age at natural menopause. Hum Mol Genet (2014) 23(9):2490-7. doi:10.1093/hmg/ddt620

9. Stolk L, Perry JR, Chasman DI, He C, Mangino M, Sulem P, et al. Meta-analyses identify 13 loci associated with age at menopause and highlight DNA repair and immune pathways. Nat Genet (2012) 44(3):260-8. doi:10.1038/ng.1051

10. Stolk L, Zhai G, van Meurs JB, Verbiest MM, Visser JA, Estrada K, et al. Loci at chromosomes 13,19 and 20 influence age at natural menopause. Nat Genet (2009) 41(6):645-7. doi:10.1038/ng.387

11. Shi L, Remer T, Buyken AE, Hartmann MF, Hoffmann P, Wudy SA. Prepubertal urinary estrogen excretion and its relationship with pubertal timing. Am J Physiol Endocrinol Metab (2010) 299(6):E990-7. doi:10.1152/ ajpendo.00374.2010

12. Elks CE, Perry JR, Sulem P, Chasman DI, Franceschini N, He C, et al. Thirty new loci for age at menarche identified by a meta-analysis of genome-wide association studies. Nat Genet (2010) 42(12):1077-85. doi:10.1038/ng.714

13. Perry JR, Stolk L, Franceschini N, Lunetta KL, Zhai G, McArdle PF, et al. Metaanalysis of genome-wide association data identifies two loci influencing age at menarche. Nat Genet (2009) 41(6):648-50. doi:10.1038/ng.386

14. Ursin G, Ross RK, Sullivan-Halley J, Hanisch R, Henderson B, Bernstein L. Use of oral contraceptives and risk of breast cancer in young women. Breast Cancer Res Treat (1998) 50(2):175-84. doi:10.1023/A:1006037823178

15. Beral V; Million Women Study Collaborators. Breast cancer and hormonereplacement therapy in the Million Women Study. Lancet (2003) 362(9382): 419-27. doi:10.1016/S0140-6736(03)14065-2

16. Cavallo F, De Giovanni C, Nanni P, Forni G, Lollini PL. 2011: the immune hallmarks of cancer. Cancer Immunol Immunother (2011) 60(3):319-26. doi:10.1007/s00262-010-0968-0

17. Chua AC, Hodson LJ, Moldenhauer LM, Robertson SA, Ingman WV. Dual roles for macrophages in ovarian cycle-associated development and remodelling of the mammary gland epithelium. Development (2010) 137(24):4229-38. doi:10.1242/dev.059261

18. Hodson LJ, Chua AC, Evdokiou A, Robertson SA, Ingman WV. Macrophage phenotype in the mammary gland fluctuates over the course of the estrous cycle and is regulated by ovarian steroid hormones. Biol Reprod (2013) 89(3):65. doi:10.1095/biolreprod.113.109561

19. Routley CE, Ashcroft GS. Effect of estrogen and progesterone on macrophage activation during wound healing. Wound Repair Regen (2009) 17(1):42-50. doi:10.1111/j.1524-475X.2008.00440.x

20. Arck P, Hansen PJ, Mulac Jericevic B, Piccinni MP, Szekeres-Bartho J. Progesterone during pregnancy: endocrine-immune cross talk in mammalian species and the role of stress. Am J Reprod Immunol (2007) 58(3):268-79. doi:10.1111/j.1600-0897.2007.00512.x

21. Goto S, Sato M, Kaneko R, Itoh M, Sato S, Takeuchi S. Analysis of Th1 and Th2 cytokine production by peripheral blood mononuclear cells as a parameter of immunological dysfunction in advanced cancer patients. Cancer Immunol Immunother (1999) 48(8):435-42. doi:10.1007/s002620050620

22. Mantovani A, Bottazzi B, Colotta F, Sozzani S, Ruco L. The origin and function of tumor-associated macrophages. Immunol Today (1992) 13(7):265-70. doi:10.1016/0167-5699(92)90008-U

23. Dasari P, Sharkey DJ, Noordin E, Glynn DJ, Hodson LJ, Chin PY, et al. Hormonal regulation of the cytokine microenvironment in the mammary gland. J Reprod Immunol (2014) 106:58-66. doi:10.1016/j.jri.2014.07.002

24. Schernhammer ES, Holly JM, Pollak MN, Hankinson SE. Circulating levels of insulin-like growth factors, their binding proteins, and breast cancer risk. Cancer Epidemiol Biomarkers Prev (2005) 14(3):699-704. doi:10.1158/10559965.EPI-04-0561

25. Wu MH, Chou YC, Chou WY, Hsu GC, Chu CH, Yu CP, et al. Relationships between critical period of estrogen exposure and circulating levels of insulinlike growth factor-I (IGF-I) in breast cancer: evidence from a case-control study. Int J Cancer (2010) 126(2):508-14. doi:10.1002/ijc.24722

26. Thordarson G, Slusher N, Leong H, Ochoa D, Rajkumar L, Guzman R, et al. Insulin-like growth factor (IGF)-I obliterates the pregnancy-associated protection against mammary carcinogenesis in rats: evidence that IGF-I enhances cancer progression through estrogen receptor-alpha activation via the mitogenactivated protein kinase pathway. Breast Cancer Res (2004) 6(4):R423-36. doi:10.1186/bcr812

27. Rijnkels M, KabotyanskiE, Montazer-Torbati MB, Hue Beauvais C, VassetzkyY, Rosen JM, et al. The epigenetic landscape of mammary gland development and functional differentiation. JMammary Gland Biol Neoplasia (2010) 15(1):85-100. doi:10.1007/s10911-010-9170-4

28. Kleinberg DL, Ameri P, Singh B. Pasireotide, an IGF-I action inhibitor, prevents growth hormone and estradiol-induced mammary hyperplasia. Pituitary (2011) 14(1):44-52. doi:10.1007/s11102-010-0257-0

29. Ruan W, Fahlbusch F, Clemmons DR, Monaco ME, Walden PD, Silva AP, et al. SOM230 inhibits insulin-like growth factor-I action in mammary gland development by pituitary independent mechanism: mediated through somatostatin subtype receptor 3? Mol Endocrinol (2006) 20(2):426-36. doi:10.1210/ me.2005-0283

30. Singh B, Smith JA, Axelrod DM, Ameri P, Levitt H, Danoff A, et al. Insulinlike growth factor-I inhibition with pasireotide decreases cell proliferation and increases apoptosis in pre-malignant lesions of the breast: a phase 1 proof of principle trial. Breast Cancer Res (2014) 16(6):463. doi:10.1186/ s13058-014-0463-1

31. Borges VF, Schedin PJ. Pregnancy-associated breast cancer: an entity needing refinement of the definition. Cancer (2012) 118(13):3226-8. doi:10.1002/ cncr. 26643

32. Lyons TR, Schedin PJ, Borges VF. Pregnancy and breast cancer: when they collide. J Mammary Gland Biol Neoplasia (2009) 14(2):87-98. doi:10.1007/ s10911-009-9119-7

33. Callihan EB, Gao D, Jindal S, Lyons TR, Manthey E, Edgerton S, et al. Postpartum diagnosis demonstrates a high risk for metastasis and merits an expanded definition of pregnancy-associated breast cancer. Breast Cancer Res Treat (2013) 138(2):549-59. doi:10.1007/s10549-013-2437-x

34. Liu Q, Wuu J, Lambe M, Hsieh SF, Ekbom A, Hsieh CC. Transient increase in breast cancer risk after giving birth: postpartum period with the highest risk (Sweden). Cancer Causes Control (2002) 13(4):299-305. doi:10.1023/ A:1015287208222

35. Gupta PB, Proia D, Cingoz O, Weremowicz J, Naber SP, Weinberg RA, et al. Systemic stromal effects of estrogen promote the growth of estrogen receptor-negative cancers. Cancer Res (2007) 67(5):2062-71. doi:10.1158/00085472.CAN-06-3895

36. Lyons TR, Borges VF, Betts CB, Guo Q, Kapoor P, Martinson HA, et al. Cyclooxygenase-2-dependent lymphangiogenesis promotes nodal metastasis of postpartum breast cancer. J Clin Invest (2014) 124(9):3901-12. doi:10.1172/ JCI73777

37. Lyons TR, O’Brien J, Borges VF, Conklin MW, Keely PJ, Eliceiri KW, et al. Postpartum mammary gland involution drives progression of ductal carcinoma in situ through collagen and COX-2. Nat Med (2011) 17(9): 1109-15. doi:10.1038/nm.2416 
38. Martinson HA, Jindal S, Durand-Rougely C, Borges VF, Schedin P. Wound healing-like immune program facilitates postpartum mammary gland involution and tumor progression. Int J Cancer (2015) 136(8):1803-13. doi:10.1002/ ijc.29181

39. Stanford JC, Young C, Hicks D, Owens P, Williams A, Vaught DB, et al. Efferocytosis produces a prometastatic landscape during postpartum mammary gland involution. J Clin Invest (2014) 124(11):4737-52. doi:10.1172/ JCI76375

40. Betterman KL, Harvey NL. The lymphatic vasculature: development and role in shaping immunity. Immunol Rev (2016) 271(1):276-92. doi:10.1111/ imr.12413

41. Schulte-Merker S, Sabine A, Petrova TV. Lymphatic vascular morphogenesis in development, physiology, and disease. J Cell Biol (2011) 193(4):607-18. doi:10.1083/jcb.201012094

42. Tammela T, Alitalo K. Lymphangiogenesis: molecular mechanisms and future promise. Cell (2010) 140(4):460-76. doi:10.1016/j.cell.2010.01.045

43. Cao Y, Linden P, Farnebo J, Cao R, Eriksson A, Kumar V, et al. Vascular endothelial growth factor $\mathrm{C}$ induces angiogenesis in vivo. Proc Natl Acad Sci U S A (1998) 95(24):14389-94. doi:10.1073/pnas.95.24.14389

44. Gallego E, Vicioso L, Alvarez M, Hierro I, Pérez-Villa L, Blanes A, et al. Stromal expression of vascular endothelial growth factor $\mathrm{C}$ is relevant to predict sentinel lymph node status in melanomas. Virchows Arch (2011) 458(5):621-30. doi:10.1007/s00428-011-1044-7

45. Karkkainen MJ, Haiko P, Sainio K, Partanen J, Taipale J, Petrova TV, et al. Vascular endothelial growth factor $\mathrm{C}$ is required for sprouting of the first lymphatic vessels from embryonic veins. Nat Immunol (2004) 5(1):74-80. doi:10.1038/ni1013

46. Klotz L, Norman S, Vieira JM, Masters M, Rohling M, Dubé KN, et al. Cardiac lymphatics are heterogeneous in origin and respond to injury. Nature (2015) 522(7554):62-7. doi:10.1038/nature14483

47. Schoppmann SF, Fenzl A, Nagy K, Unger S, Bayer G, Geleff S, et al. VEGF-C expressing tumor-associated macrophages in lymph node positive breast cancer: impact on lymphangiogenesis and survival. Surgery (2006) 139(6):839-46. doi:10.1016/j.surg.2005.12.008

48. Boyapati SM, Shu XO, Gao YT, Dai Q, Yu H, Cheng JR, et al. Correlation of blood sex steroid hormones with body size, body fat distribution, and other known risk factors for breast cancer in post-menopausal Chinese women. Cancer Causes Control (2004) 15(3):305-11. doi:10.1023/B:CACO.0000024256.48104.50

49. Hankinson SE, Willett WC, Manson JE, Hunter DJ, Colditz GA, Stampfer MJ, et al. Alcohol, height, and adiposity in relation to estrogen and prolactin levels in postmenopausal women. J Natl Cancer Inst (1995) 87(17):1297-302. doi:10.1093/jnci/87.17.1297

50. McTiernan A, Wu L, Chen C, Chlebowski R, Mossavar-Rahmani Y, Modugno F, et al. Relation of BMI and physical activity to sex hormones in postmenopausal women. Obesity (Silver Spring) (2006) 14(9):1662-77. doi:10.1038/ oby.2006.191

51. Lorincz AM, Sukumar S. Molecular links between obesity and breast cancer. Endocr Relat Cancer (2006) 13(2):279-92. doi:10.1677/erc.1.00729

52. Brown KA, McInnes KJ, Hunger NI, Oakhill JS, Steinberg GR, Simpson ER. Subcellular localization of cyclic AMP-responsive element binding proteinregulated transcription coactivator 2 provides a link between obesity and breast cancer in postmenopausal women. Cancer Res (2009) 69(13):5392-9. doi:10.1158/0008-5472.CAN-09-0108
53. Zhao Y, Agarwal VR, Mendelson CR, Simpson ER. Transcriptional regulation of CYP19 gene (aromatase) expression in adipose stromal cells in primary culture. J Steroid Biochem Mol Biol (1997) 61(3-6):203-10. doi:10.1016/ S0960-0760(97)80013-1

54. Au CC, Docanto MM, Zahid H, Raffaelli FM, Ferrero RL, Furness JB, et al. Des-acyl ghrelin inhibits the capacity of macrophages to stimulate the expression of aromatase in breast adipose stromal cells. J Steroid Biochem Mol Biol (2017) 170:49-53. doi:10.1016/j.jsbmb.2016.07.005

55. Docanto MM, Yang F, Callaghan B, Au CC, Ragavan R, Wang X, et al. Ghrelin and des-acyl ghrelin inhibit aromatase expression and activity in human adipose stromal cells: suppression of cAMP as a possible mechanism. Breast Cancer Res Treat (2014) 147(1):193-201. doi:10.1007/s10549-0143060-1

56. Cheang MC, Voduc KD, Tu D, Jiang S, Leung S, Chia SK, et al. Responsiveness of intrinsic subtypes to adjuvant anthracycline substitution in the NCIC. CTG MA.5 randomized trial. Clin Cancer Res (2012) 18(8):2402-12. doi:10.1158/1078-0432.CCR-11-2956

57. Chia SK, Bramwell VH, Tu D, Shepherd LE, Jiang S, Vickery T, et al. A 50-gene intrinsic subtype classifier for prognosis and prediction of benefit from adjuvant tamoxifen. Clin Cancer Res (2012) 18(16):4465-72. doi:10.1158/10780432.CCR-12-0286

58. Kariagina A, Xie J, Leipprandt JR, Haslam SZ. Amphiregulin mediates estrogen, progesterone, and EGFR signaling in the normal rat mammary gland and in hormone-dependent rat mammary cancers. Horm Cancer (2010) 1(5):229-44. doi:10.1007/s12672-010-0048-0

59. Fata JE, Chaudhary V, Khokha R. Cellular turnover in the mammary gland is correlated with systemic levels of progesterone and not 17beta-estradiol during the estrous cycle. Biol Reprod (2001) 65(3):680-8. doi:10.1095/ biolreprod65.3.680

60. Ramakrishnan R, Khan SA, Badve S. Morphological changes in breast tissue with menstrual cycle. Mod Pathol (2002) 15(12):1348-56. doi:10.1097/01. MP.0000039566.20817.46

61. Bueno-de-Mesquita JM, van Harten WH, Retel VP, van 't Veer LJ, van Dam FS, Karsenberg $\mathrm{K}$, et al. Use of 70 -gene signature to predict prognosis of patients with node-negative breast cancer: a prospective community-based feasibility study (RASTER). Lancet Oncol (2007) 8(12):1079-87. doi:10.1016/ S1470-2045(07)70346-7

62. Drukker CA, Bueno-de-Mesquita JM, Retèl VP, van Harten WH, van Tinteren $\mathrm{H}$, Wesseling J, et al. A prospective evaluation of a breast cancer prognosis signature in the observational RASTER study. Int J Cancer (2013) 133(4):929-36. doi:10.1002/ijc.28082

Conflict of Interest Statement: The authors declare that the research was conducted in the absence of any commercial or financial relationships that could be construed as a potential conflict of interest.

Copyright $\odot 2017$ Anderson, Ingman and Britt. This is an open-access article distributed under the terms of the Creative Commons Attribution License (CC BY). The use, distribution or reproduction in other forums is permitted, provided the original author(s) or licensor are credited and that the original publication in this journal is cited, in accordance with accepted academic practice. No use, distribution or reproduction is permitted which does not comply with these terms. 